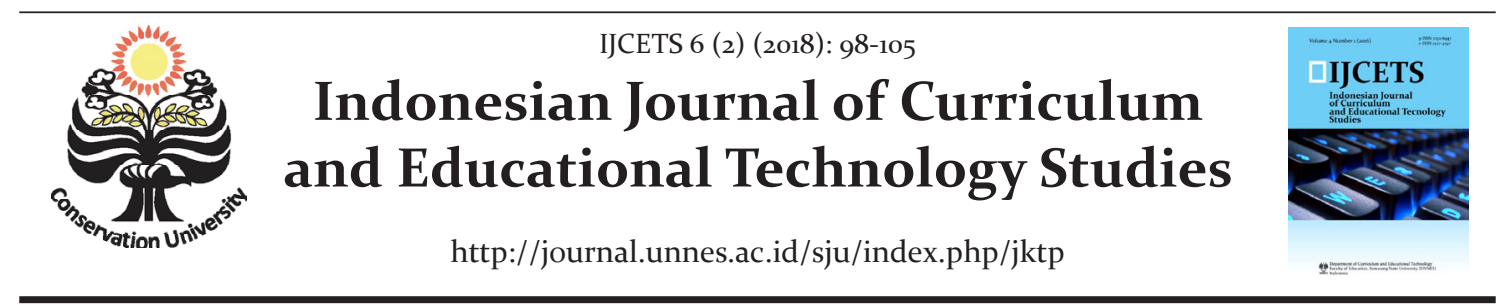

\title{
What Type of Curriculum Development Models Do We Follow? An Indonesia's 2013 Curriculum Case
}

\author{
Dyah Tri Palupi ${ }^{\bowtie}$
}

'Pusat Kurikulum dan Perbukuan, Badan Penelitian dan Pengembangan, Kementerian Pendidikan dan Kebudayaan, Jakarta, Indonesia

DOI: https://doi.org/10.15294/ijcets.v6i2.26954

\section{Article History \\ Received : September 2018 Accepted : October 2018 \\ Published : November 2018}

\section{Keywords}

Contextual curriculum; curriculum as praxis; curriculum development; eclectic model; the Indonesia's 2013 national curriculum

\begin{abstract}
Abstrak
Artikel ini mengkaji Kurikulum 2013 dari berbagai jenis model-model pengembangan kurikulum, seperti model Tyler, Taba, Wheeler, Nicholls \& Nicholls, Tanner \& Tanner, Stenhause, Cornbleth, dan Doll. Dengan mengkaji secara teliti dokumen-dokumen resmi kebijakan Kurikulum 2013 penulis menyimpulkan bahwa Kurikulum 2013 dapat dikategorisasikan sebagai bertipe "baru" yang lebih bersifat eklektik dengan mengikuti gagasan kurikulum sebagai praksis. Kecenderungan eklektik dari kurikulum ini dapat dilihat dari orientasinya yang mencoba untuk mengakmodasi banyak gagasan dari beberapa model pengembangan kurikulum dari Tyler hingga Doll. Misalnya, Kurikulum 2013 masih menggunakan perspektif standardisasi sebagai mekanisme control terhadap mutu lulusan, muatan kurikulum, dan proses pembelajaran, tapi di sisi lain Kurikulum 2013 juga mengarahkan sekolah-sekolah untuk mengembangkan kurikulum yang sifatnya kontekstual. Kurikulum 2013 juga mengkompromikan antara desain kurikulum berbasis luaran/kompetensi dan berbasis proses yang terkadang justru menyulitkan para guru dalam melakukan penilaian hasil belajar siswa di sekolah.
\end{abstract}

\footnotetext{
Abstract

This article identifying the Indonesi's 2013 curriculum policy from several types of curriculum development models such as Tyler, Taba, Wheeler, Nicholls E Nicholls, Tanner E Tanner, Stenhause, Cornbleth and Doll. By analyzing carefully the official curriculum policy the author conclude that the 2013 curriculum could be classified as a "new" type of curriculum which is more eclectic by following the idea curriculum as praxis. The eclectic mode of the curriculum could be trace from its orientation to accommodate lots of idea from various curriculum development models from Tyler to Doll, for instance 2013 curriculum still has a tendency to control the standard of the learning outcome, content and process, but in other hand this curriculum encourages to develop a more contextual curriculum design for all of the schools throughout Indonesia. The 2013 curriculum also makes a compromise between outcome/competency-based and process-based curriculum design in which sometimes make the assessment process become a little bit difficult for the teachers at schools.
}

$\bowtie$ Corresponding author : Address: Jl. Gunung Sahari Raya No. 4 Jakarta Pusat, 10610

E-mail: dyahtri.dtp@gmail.com
(C) 2018 Universitas Negeri Semarang p-ISSN 2252-6447 e-ISSN 2527-4597 


\section{INTRODUCTION}

Since the beginning of the development of curriculum studies as a discipline there were lots of models of curriculum development created by many scholars. Many references describe it clearly, for instances Ornstein \& Hunkins (2018), Flinders \& Thornton (2004), Smith (1996, 2000) and many more, especially encounter references to curriculum studies. For the academicians who concern on curriculum studies and also curriculum developers in many areas knowing and mastering various curriculum models as well as understanding its foundations, principles and issues are necessary. Moreover, in Indonesian context after the issuance of the 2006 national curriculum in which all the schools required to have their own curriculum, so all of the teachers at schools, particularly the top management of the school, mastering the curriculum development models is a must.

Of course it was a good achievement for the Ministry of Education and Culture (MoEC) in order to encourage the awareness all of the school's members that they have immense responsibility to develop more contextual curriculum. Furthermore, it seems that this policy was difficult for the teachers (i.e. Melati \& Utanto, 2016; Siambaton et al., 2016; Subekti et al., 2016; Sutrisno et al., 2017; \& Kastawi et al. 2017), because most of them do not have academic background on curriculum studies. Most of the teacher did not really understand the basic concept and how to implement properly the 2013 national curriculum orientation (i.e. Ahmad, 2014; Ekawati, 2016; Retnawati et al., 2016; Kastawi et al., 2017; \& Suyanto, 2017). Whereas understanding the theoretical base of the curriculum is important for ones who want to develop a curriculum, if not they will potentially trapped only on technical terms how to develop the curriculum procedurally.

In Western tradition of curriculum studies we could find lots of scholars whose concern were on theoretical dimension of curriculum. For instances Hunkins \& Hammil (1994) who reconceptualizing the curriculum process beyond Tyler and Taba, Chikumbu \& Makamure (2000) and Chaudhary \& Kalia (2015) comparing Tyler's model, Wheeler's model and Kerr's model of curriculum development. Lunenburg (2011a, 2011b) also analyze and categorize of several curriculum models, i.e. Taba's instructional strategies model, Weinstein and Fantini's humanistic model, Eisner's systemic-aesthetic model,
Beauchamp's managerial model, and Saylor, Alexander and Lewis's administrative model. A few examples above at least could represent several scholars who concern on studying the details of the theoretical base of the curriculum, especially on various models of curriculum development.

Moreover, on certain and specific context many scholars also develop a comparative study of curriculum. At this point Pinar (2008) published a magnificent works as a collection of a numbers of studies on curriculum from 28 countries. In other case Chen, Chen, \& Cheng (1996) comparing the objective model of curriculum between America and Taiwan and found some similarities on the concept and some differences in implementation. In this case, in Indonesian context, Widyastono (2014) tried to investigate the development of national curriculum of 2004, 2006 and 2013. Wahyuni (2015) also tracing the historical of the Indonesian national curriculum and conclude that all of the changes were under such political, cultural, economics, and also the development of science and technology encouragement. In accordance to Wahyuni, Subkhan (2018) investigating that ideology and political power influence the Indonesian national educational system, including its curriculum orientation.

Actually, there were lots of scholars who studied curriculum focusing on the curriculum changes in Indonesia and the problems that follow, but there was lack of literature concerning on analyzing critically the model of curriculum and the theoretical discourse behind the development of the national curriculum. There were only few scholars who have a huge interest in this topic, e.g. Hasan (2000), Gufron (2008), Alwasilah (2012), Watson (2012), Albertus (2013), Subandi (2014), Rusli (2017), Hartono et al. (2018). In an attempt to make a clear academic explanation on the differences and similarities of certain curriculum development models, the comparative study is a must. This article is a literature review article in which the author tries to identify the curriculum development model of the 2013 national curriculum.

\section{COMPARING SEVERAL MODELS OF CUR- RICULUM DEVELOPMENT}

In this section the author would compare several models of curriculum development from several prominent scholars, and will be ended by classified all of those models into several categories. 
First, be referring to Doll (2012) the very early development of curriculum was in the form of subject-matter curriculum model. This type also well known as classical curriculum model, in which addressed the learning process on certain basic textbooks that should be mastered by the students. It means curriculum has a limited meaning only as a collection of textbooks for the student. This conception had been employed by two oldest universities in Europe since the 17th century, i.e. Leiden University and Glasgow University. Actually the character of classical curriculum still has great influence on the development of curriculum in many contexts, including in Indonesia.

Second, in the next periods, the scientific management from Frederic Taylor had influenced not only on industrial and business field, buy also on education. Scientific management counted the important of measurement of everything in order to make sure its achievement or failure. One of the early scholars on curriculum studies, Tyler (1949) develops a curriculum model based on Taylor's scientific management. In this model, the aims of the educational and learning practices had been established in the early stage of the development process in the form of measured indicators. The aims of the education and learning should be derived from the analysis of the personal's need to be a successful person in the future and society's need to build a democratic and humanist civilization.

Moreover, by referring to Dewey and Bobbit, Tyler agreed that curriculum is a set of experiences should be experienced by the students. The successful of the model could be measured by evaluating the student learning outcome in the end of the learning process. Tyler's model is revolutionary because it reverses the classical model from the supply-oriented toward more demand-oriented design. The rise of Tyler's curriculum model encourages the rise of many curriculum models later.

Third, Taba (1962) by evaluating the Tyler's model develop a curriculum model as a middle ground between the classical and Tyler's model. She inserts some details steps on choosing and organizing the learning materials (content) before choosing and organizing the learning experiences. In this case, the classical curriculum models emphasizes and prioritizes the learning materials unlike Tyler's model in which more emphasizes on learning experiences. Taba's model also creates a space for the teachers to enrich the learning practices by accommodating the scattered materials around their learning context, so the students' experiences compatible with their daily life. Furthermore, Tyler and Taba's curriculum models were well known as a linier model, because the steps of the development were under the sequential logic of thinking. We could see this character clearly, because it is started with the formulation of the learning aims and ended with evaluation process. Of course these models of curriculum development have several criticisms, one of them targeting on the rigid character of the model in which ended up in the evaluation process.

Fourth, by criticizing Tyler and Taba's curriculum models, Wheeler (1967) create a different style of model. He argued that curriculum development shouldn't have starting and/or ending stages, because in facts learning practices in schools or in real live do not have clear starting or ending point. Learning activities are always spinning and correcting it continuously. The evaluation result becomes the recommendation for the reformulation of the next learning steps by improving the needs and purposes of the learning practices. In this model "process" would repeat permanently according to the continuous improvement theory. Therefore, Wheeler creates a circular/cyclical curriculum model as opposed to Tyler and Taba's models.

Moreover, Wheeler also changes the process of the curriculum development model by putting learning experiences first before choosing and organizing the learning materials. In other words, the curriculum development should begin with determining the learning experiences, and based on these experiences the curriculum designer prepare the materials and content of learning to pursue those experiences. This model prevents to avoid the mismatch of the learning materials with the students' daily life and need.

Fifth, in the next period Stenhause and Kolb separately develop a model that emphasize on the learning process than the learning material and purpose. Stenhause (1975) argue the important of the learning process to develop a curriculum, and he insists the "learning process" should be main focus in order to give a meaningful learning experience for the student and used it to develop their inner potentials. Kolb (1984, 2015) proposes the experiential learning cycle as a learning model in order to give the students concrete experiences with clear goal oriented. 
Within the cycle student think critically and reflect their learning experiences and then conceptualizes it abstractly to gain a conceptual understanding.

Sixth, with the same spirit, Grundy and Cornbleth also propose a curriculum model as an alternative to classical and linier model of curriculum development. Firstly Grundy (1987) compare the concept of curriculum as product and praxis as a comparison of Tyler to Stenhause's model. Grundy did not used the term "process" on his model, because it is not enough to replace the Tyler's model and its follower, so he used the term "praxis" to emphasize the important of the learning purpose and material as a part of the learning development program, but by put the "process" as the central of the model. In this case, Smith $(1996,2000)$ strengthen that praxis as the improvement of the "process" to ensure that learning purpose and material are still necessary as long as it is contextual in nature (see also Cornbleth, 1990).

The combination of such perspectives produce a curriculum model based on student empowerment by attracting the student to actively understand and use their daily environment wisely and responsibly. It means that GrundyCornbleth curriculum model become an accommodative curriculum in which friendly with the diversity of the context of the school as well as with the various values, psycho-socio-economic background of the student.

Seventh, by analyzing critically to the domination of Tyler's curriculum model and its followers, Doll $(1993,2012)$ proposes a post-modern curriculum development model. He saw that Tyler's model and its followers did not put the student as a fully human with various identities, potentials, needs and the purposes of the life. So, the student learning activities cannot be developed in a linier or cyclical way of thinking as a standardized process to all of students. Doll saw student as the subject of the learning process in which has the ability to improve him or herself. The necessary thing outside from his or herself is the stimulus to recognize his or her potentials, his or her weakness and excellence.

Post-modern curriculum model proposed by Doll $(1993,2012)$ is so natural, non-linier, non-sequential and chaotic all of the time of the learning process. Through natural, non-linier, non-sequential or even chaotic process the student find his or her potentials, weakness and excellence and then create his or her own curriculum. It means the learning practices should be based on discovery as well as Kolb curriculum model proposed previously. Doll's post-modern curriculum development model emphasize on the students learning experiences that must be experienced by them in order to look at their potentials. At his point Doll proposes 4's basic principles, i.e. richness, recursion, relation and rigor.

Eight, in 1968 Jackson proposed the term "hidden curriculum" as an important factor that encourage the some students having significant differences on changing or achieving some learning outcomes than others. It called "hidden curriculum" because the content of the materials do not appeared in the official curriculum document, but the teachers always emphasize some values, traditions, worldviews or attitudes as a part of the learning practices. The substances of the materials relates to the formation of the student worldviews, values, attitudes and characters. For Tanner \& Tanner (1995) those "hidden curriculum" is more accurately referred as collateral curriculum by referring to Dewey (1938). At this point Jackson's (1968) hidden curriculum concept inspires Tanner \& Tanner curriculum model in which emphasize the formation of the student's character in the process of the curriculum development.

Curriculum also could be classified at least into four categories, i.e. material, product, process and praxis (see Kelly, 2004). First, curriculum as a material situated the subject matter as a focus of curriculum development and textbook plays important role as a required reading and the only duty of the teacher is to deliver the content of the book to the student. In this case the book material is perceived as absolute by teacher as well as by student, it is why this category has been labeled as absolutism and classical definition of curriculum. Secondly, curriculum as product perceived the learning outcome or the product of the learning process as the focus of the curriculum development. Compare to the previous category in which the curriculum development process derived from body of knowledge into subject matter and the aims of education, in curriculum as product it would first define the aims of the education before establish the subject should be learn by the student.

Thirdly, curriculum as process posits learning process as the central of the learning development activity. The aims of education and the subject were loosely developed in the learning 
process. This type of curriculum assumes that each child has a special learning need and in line with constructivism paradigm and pragmatism philosophy it is necessary to develop a contextual and personalized curriculum and learning practice (Kelly, 2004). Fourth, in fact curriculum as praxis has similar philosophical base with curriculum as process, but unlike the former type of curriculum development model in which looks like letting the learning practices run without fixed purposes, the curriculum as praxis placing the learning material and objective as an important and integrated element of the curriculum development process but with contextual emphasis.

Curriculum as praxis based on eclectic notion combines the process, contextual learning material and objective. Moreover, the student achievement was formulated flexibly by appreciating the cultural and socio-economic diversities background. According to the discussion above we could classify the Tyler, Taba, Wheeler, Nicholls and Tanner's model emphasize their model as curriculum as product, Stenhause and Kolb based their model on the curriculum as process and Grundy, Cornbleth and Doll's model could be categorize into curriculum as praxis. Actually, the diversity of the various curriculum development models are caused by several factors, i.e. its orientations, approaches, and educational paradigm or philosophy in which influences the ideal reason of the aim of education, the position of student and teacher, and etc. Table 1 below summarizes the explanation above.

\section{INDONESIAN NATIONAL CURRICULUM OF 2013}

According to the discussion previously, it is clear that understanding and mastering the various models of curriculum development is necessary. Furthermore the author would bring the Indonesia's 2013 national curriculum into discussion. The author argues by considering the Act No. 20 of $\mathbf{2 0 0 3}$ on national education system that the basic concept of curriculum had been used by the government to design the national curriculum has accommodated several models derived from Taba (1962), Wheeler (1967), Nicholls \& Nicholls (1981), Grundy-Cornbleth (1987 \& 1990) and Tanner \& Tanner (1995). The construction of national curriculum of 2013 has been developed based on the definition of curriculum on Act No. 20 of 2003 on national education system.

In this case we could see the eclectic notion of the model from the various sides, for instance the model emphasizes student outcome or competency as the central of the development process to establish the learning purposes, process and assessment, but in other hand we could also see that it also emphasizes the socio-cultural context as an important consideration to develop school's level curriculum design (see Ministry of Education and Culture Regulation No. 23 of 2016 on national assessment standard, Ministry of Education and Culture Regulation No. 24 of 2016 on 2013 curriculum core competency and subject basic competency on primary and secondary education, Government Regulation No. 32 of

Table 1 Curriculum Development Models Comparison

\begin{tabular}{|c|c|c|c|c|}
\hline \multirow{2}{*}{$\begin{array}{l}\text { Elements/ } \\
\text { classification }\end{array}$} & \multicolumn{4}{|c|}{ Curriculum as ... } \\
\hline & Material & Product & Process & Praxis \\
\hline $\begin{array}{l}\text { Orientation/ } \\
\text { focusing on ... }\end{array}$ & Planning & Purpose & Activity & $\begin{array}{l}\text { Planned activity with } \\
\text { flexible purposes }\end{array}$ \\
\hline Approaches & Theoretical & $\begin{array}{l}\text { Productive/ } \\
\text { outcome-based }\end{array}$ & Practice & Praxis \\
\hline $\begin{array}{l}\text { The function of } \\
\text { education }\end{array}$ & $\begin{array}{l}\text { Transfer of } \\
\text { knowledge }\end{array}$ & $\begin{array}{l}\text { Instrumental skills } \\
\text { development }\end{array}$ & $\begin{array}{l}\text { Student potential } \\
\text { development }\end{array}$ & $\begin{array}{l}\text { Achieving student skills } \\
\text { trough the development } \\
\text { of student potentia }\end{array}$ \\
\hline Paradigm & Absolutism & Instrumentalism & Pragmatism & Eclectic \\
\hline $\begin{array}{l}\text { The role of } \\
\text { student }\end{array}$ & $\begin{array}{l}\text { Knowledge } \\
\text { receiver }\end{array}$ & $\begin{array}{l}\text { Learning raw } \\
\text { material }\end{array}$ & Active learning actor & $\begin{array}{l}\text { Planner and active learn- } \\
\text { ing actor }\end{array}$ \\
\hline $\begin{array}{l}\text { The role of } \\
\text { teacher }\end{array}$ & $\begin{array}{l}\text { Knowledge } \\
\text { organizer }\end{array}$ & $\begin{array}{l}\text { Experience } \\
\text { organizer }\end{array}$ & $\begin{array}{l}\text { Empowering student } \\
\text { potential }\end{array}$ & $\begin{array}{l}\text { Formulating the experi- } \\
\text { ence and learning con- } \\
\text { text in order to empower } \\
\text { the student potential }\end{array}$ \\
\hline
\end{tabular}


2013 on change over the Government Regulation No. 19 of 2005 on education national standard). It means that 2013 national curriculum cannot be classified into curriculum as product only, the curriculum as praxis may be more correct because its development model also emphasize the learning purpose and process as the important factors as had been written officially on its document.

The diversity of Indonesian cultures, values, ethnics, religions and regions have officially encourage the curriculum development process to accommodate a local content for local student. So it is strongly recommended that every region have their unique local content, for example in Central Java the government released officially the Javanese language as local content that must be studied by all of student in Central Java province (Palupi, 2016). Moreover, every school also directed to develop a contextual curriculum by reconsidering the school's social milieu, problems, the diversity of the student economic and social background and their personal and social potential. Thus it can be concluded that 2013 curriculum design has at least three level contexts, i.e. local, national and international content (Subkhan, 2016).

Moreover, if we look at the main idea of the 2013 national curriculum we could see that this curriculum design did not maintain the local content as a separated learning process, but treat it as a context of all the learning materials (Kasim, 2014). It means that all of the learning materials should be contextualize first before being taught to the student in order to bring the student closer with their daily problems and make the learning process more meaningful and useful for them. Therefore, to ensure the implementation of 2013 curriculum in line with the accommodative notion of the curriculum, the formulation of the learning process-which is central in 2013 curriculum design-should be based on contextual activities. In other terms, 2013 curriculum accommodate the formal, informal and collateral curriculum into one package.

Theoretically the 2013 curriculum design uses Kolb's model on developing the learning process trough observing, thinking and trying to gain a concrete learning experiences and has been equipped by Dyers' et al. (2009) finding about the important of associating and communicating activities on enhancing the student creativity. This tendency has been establish on the 2013 curriculum's document officially which is based on Act No. 20 of 2003 on national education system. We could also see the standardization orientation of the curriculum when we recognize that Indonesian education system also establish four national education standards, i.e. outcome, content, process and assessment standard.

\section{CONCLUSION}

According to the discussion above the author conclude that the 2013 Indonesian national curriculum following the notion of curriculum as praxis in which elaborating the importance of the learning process, its aims and contextual content and also its assessment to enhance the student attitude, knowledge and skills as a whole unit of curriculum. We could see the Tyler style and several contemporary curriculum development models on 2013 curriculum in which different from the old Indonesian national curriculum on 1990s era who still laid on classical idea of curriculum as product only. The 2013 curriculum accommodate a contemporary idea that learning process has an important role to gain student's competencies-more than emphasize on learning aim and content only, this curriculum design also encourage to develop a more contextual content and learning process. At least, 2013 curriculum already accommodate eclectically several curriculum development models from Tyler, Kolb, Grundy, Cornbleth and Doll.

\section{REFERENCES}

Ahmad, D. (2014). Understanding the 2013 Curriculum of English Teaching through the Teachers' and Policymakers' Perspectives. International Journal of Enhanced Research in Educational Development, 2(4), 6-15.

Albertus, D.K. (2013, April 5). Eklektisisme Kurikulum 2013. Kompas. 5.

Alwasilah, A.C. (2012, October 19). Cross-curricular teaching is vital in primary education. The Jakarta Post.

Chaudhary, G.K., \& Kalia, R. (2015). Development Curriculum and Teaching Models of Curriculum Design for Teaching Institutes. International Journal of Physical Education, Sports and Health, 1(4), 57-59.

Chen, C., Chen, Y., \& Cheng, K. (1996). A study on comparing the objective model in curriculum planning between Taiwan and America. Retrieved from http://rnd2.ncue.edu.tw/ezcatfiles/boo4/img/img/316/96-1-8p.pdf.

Chikumbu, T.J. \& Makamure, R. (2000). Curriculum Theory, Design and Assessment. The Commonwealth of Learning. 
Cornbleth, C. (1990). Curriculum in Context. London: Falmer Press.

Dewey, J. (1938). Experience and Education. New York: Macmillan.

Doll, W.E. (1993). A Post-Modern Perspective on Curriculum. New York: Teachers College Press.

Doll, W.E. (2012). Complexity and the Culture of Curriculum. Complicity: An International Journal of Complexity and Education, 9(1), 10-29.

Dyer, J.H., Gregesen, H.B., \& Christensen, C.M. (2009, December). The Innovator's DNA. Harvard Business Review. Retrieved from https://.hbr. org/2009/12/the-innovators-dna

Ekawati, Y.N. (2016). The Implementation of Curriculum 2013: a Case Study of English Teachers' Experience at SMA Lab School in Indonesia. ELLD Journal, (1), 84-90.

Flinders, D.J. \& Thornton, S.J. (Eds.). (2004). The Curriculum Studies Reader. 2nd Edition. London $\&$ New York: RoutledgeFalmer.

Government of Republic Indonesia. (2013). Government Regulation No. 32 of 2013 on change over the Government Regulation No. 19 of 2005 on education national standard. Jakarta.

Grundy, S. (1987). Curriculum: Product or Praxis. New York: Falmer Press.

Gufron, A. (2008). Filsafat Pengembangan Kurikulum. Fondasia: Majalah Ilmiah Fondasi Pendidikan, 1(9), 1-10.

Hartono, Y., Haryanto, S., \& Asrowi, S. (2018). Character Education in the Perspective of Humanistic Theory: A Case Study in Indonesia. Educare: International Journal for Educational Studies, 10(2), 95-108.

Hasan, S.H. (2006). Perkembangan Kurikulum: Perkembangan Ideologis dan Teoretik Pedagogis (1950-2005). Retrieved from http://www. geocities.ws/konferensi-nasionalsejarah/s_ hamid_hasan.pdf

Hunkins, F.P. \& Hammil, P.A. (1994). Beyond Tyler and Taba: Reconceptualizing the Curriculum Process. Peabody Journal of Education, 69(3), 4-18.

Jackson, P.W. (1968). Life in Classrooms. New York: Holt, Rinehart and Winston, Inc.

Kasim, M. (2014). Kedudukan Muatan Lokal dalam Kurikulum 2013 [PowerPoint Slides] Retrieved from: https://slideplayer.info/slide/3116065/

Kastawi, N.S., Widodo, S., \& Mulyaningrum, E.R. (2017). Kendala dalam Implementasi Kurikulum 2013 di Jawa Tengah dan Strategi Penanganannya. Indonesian Journal of Curriculum and Educational Technology Studies, 5(2), 66-76.

Kelly, A.V. (2004). The Curriculum: Theory and Practice. 5th Edition. London, Thousand Oaks, New Delhi: SAGE Publications.

Kolb, D.A. (1984, 2015). Experiential Learning: Experience as the Source of Learning and Development. 2nd Edition. New Jersey: Pearson Education.

Lunenburg, F.C. (2011a). Curriculum Development: Deductive Models. Schooling, 2(1), 1-7.
Lunenburg, F.C. (2011b). Curriculum Development: Inductive Models. Schooling, 2(1), 1-7.

Melati, E.R. \& Utanto, Y. (2016). Kendala Guru Sekolah Dasar dalam Memahami Kurikulum. Indonesian Journal of Curriculum and Educational Technology Studies, 4(1), 1-9.

Ministry of Education and Culture. (2016). Ministry of Education and Culture Regulation No. 23 of 2016 on national assessment standard. Jakarta.

Ministry of Education and Culture. (2016). Ministry of Education and Culture Regulation No. 24 of 2016 on 2013 curriculum core competency and subject basic competency on primary and secondary education. Jakarta.

Nicholls, A. \& Nicholls, H. (1981). Developing a curriculum: A practical approach. George Allen \& Unwin Ltd.

Ornstein, A.C. \& Hunkins, F.P. (2018). Curriculum: Foundations, Principles, and Issues. 7th Edition. Harlow, Essex: Pearson Education.

Palupi, D.T. (2016). Cara Mudah Memahami Kurikulum. Surabaya: Jaring Pena.

Pinar, W.F. (Ed.). (2008). International Handbook of Curriculum Research. New Jersey \& London: Lawrence Erlbaum Associates.

Retnawati, H., Hadi, S., \& Nugraha, A.C. (2016). Vocational High School Teachers' Difficulties in Implementing the Assessment in Curriculum 2013 in Yogyakarta Province of Indonesia. International Journal of Instruction, 9(1), 33-47.

Rusli. (2017). Curriculum 2013 in Relation to Education for Sustainable Development in Indonesia: Why, What, and How. Transformasi: Jurnal Kepemimpinan dan Pendidikan Islam, 1(1), 29-35.

Siambaton, H.R., Erlinawati, \& Haryanto. (2016). Problem Implementasi Kurikulum 2013 Mata Pelajaran Ilmu Pengetahuan Sosial di Jenjang Sekolah Menengah Pertama. Indonesian Journal of Curriculum and Educational Technology Studies, 4(1), 10-16.

Smith, M. K. (1996, 2000). What is Curriculum? Exploring Theory and Practice. Retrieved from http://infed.org/mobi/curriculum-theoryand-practice/

Stenhause, L.A. (1975). An Introduction to Curriculum Research and Development. London: Heinemann Educational Books.

Subandi. (2014). Indonesian Curriculum Development: Meaning-Based Curriculum and Competency-Based Curriculum in the Context of Teaching English Subject. The $2^{\text {nd }}$ International Conference on Education and Language. Universitas Bandar Lampung.

Subekti, A., Yudha, S.S., \& Budisantoso, H.T.L. (2016). Pemahaman dan Peran Guru TIK dalam Implementasi Kurikulum 2013 di Sekolah Menengah Atas. Indonesian Journal of Curriculum and Educational Technology Studies, 4(1), 25-31.

Subkhan, E. (2016). Pendidikan Kritis: Kritik atas Praksis Neo-Liberalisasi dan Standardisasi 
D.T. Palupi/Indonesian Journal of Curriculum and Educational Technology Studies 6(2) (2018): 98-105

Pendidikan. Yogyakarta: Ar-Ruzz Media.

Subkhan, E. (2018). Ideologi, Kekuasaan, dan Pengaruhya pada Arah Sistem Pendidikan Nasional Indonesia (1950-1965). Journal of Indonesian History, 7(1), 19-34.

Sutrisno, R., Widyaningsih, W., Asih, N., \& Istyarini. (2017). Kendala Pelaksanaan Layanan Teknologi Informasi \& Komunikasi dalam Kurikulum 2013. Indonesian Journal of Curriculum and Educational Technology Studies, 5(1), 22-32.

Suyanto, S. (2017). A Reflection on the Implementation of a New Curriculum in Indonesia: A Crucial Problem on School Readiness. The $4^{\text {th }}$ International Conference on Research, Implementation, and Education of Mathematic and Science. Universitas Negeri Yogyakarta.

Taba, H. (1962). Curriculum Development: Theory and Practice. New York: Harcourt, Brace and World.
Tanner, D., and Tanner, L. (1995). Curriculum Development: Theory into Practice. 3rd Edition. New Jersey: Merril.

Tyler, R.W. (1949). Basic Principles of Curriculum and Instruction. Chicago: University of Chicago Press.

Wahyuni, F. (2015). Kurikulum dari Masa ke Masa: Telaah atas Pentahapan Kurikulum Pendidikan di Indonesia. Al-Adabiya, 10(2), 231-242.

Watson, C.W. (2012, October 23). Indonesian Government is Right to Change the Curriculum. Jakarta Globe.

Wheeler, D.K. (1967). Curriculum Process. London: University of London.

Widyastono, H. (2014). Pengembangan Kurikulum di Era Otonomi Daerah: dari Kurikulum 2004, 2006, ke Kurikulum 2013. Jakarta: Bumi Aksara. 